\title{
The Economic Role of the Portuguese Agricultural Cooperatives
}

João Rebelo ${ }^{1}$ and José Caldas ${ }^{2}$

\begin{abstract}
Since 2008 Portugal began to be influenced by a financial crisis, public budget troubles and an economic crisis. In line with the new economic paradigm within the EU, is publicly acknowledged that the overcoming of this crisis should be based on the production of transactional goods, where the agricultural sector deserves a special attention. The objective of this paper is to analyze the economic role of the Portuguese agricultural marketing cooperatives, including an overview of the Portuguese agricultural sector, the typology of Portuguese cooperatives and position in the agro food chain, the institutional environment, internal governance and performance of the agricultural cooperatives.
\end{abstract}

Key-words: Portuguese agricultural cooperatives, institutional environment, internal governance.

JEL Classification: D23, Q13.

DOI: http://dx.doi.org/10.1590/1234-56781806-94790053s01007

1. Full-Professor, Ph.D in Economics at the University of Trás-os-Montes e Alto Douro (UTAD). VicePresident of the Scientific Council of the School of Human and Social Sciences. Member of the Advisor Board of UTAD. Expert in cooperative topics. E-mail: jrebelo@utad.pt

2. Associate Professor, Ph.D in Economics at the University of Trás-os-Montes e Alto Douro (UTAD). Director of the Graduate and Undergraduate Programs in Economics at UTAD. E-mail: jcaldas@utad.pt 


\section{Introduction}

Since 2008 Portugal began to be influenced by a financial crisis, next in line the public budget troubles and a consequential economic crisis. Moreover, after 2011, Portugal is under a bailed out program of troika (IMF, EU and ECB). The country has been a chronic underachiever, suffering from years of low growths, and since its rescue embraced salvation through austerity and structural reforms. Unit labor costs have fallen and exports are rising, but not enough to compensate the decrease in domestic consumption and investment. Consequently, the recession has been deeper than expected, unemployment is forecast to reach $19 \%$ in 2013, the gross domestic product (GDP) decreased and the debt-to-GDP increased. Credit for small and sized firms is especially tight.

In line with the new economic paradigm within the EU, in Portugal is also publicly acknowledged that the overcoming of this crisis should be based on the production of transactional goods, with the economic growth and development supported on endogenous resources, knowledge and innovation, where the agricultural sector deserving a special attention.

As the European Commission recognizes one of the restrictions to the European agricultural development is rooted in the imbalances in bargaining power between the contracting parties in the food supply chain, being committed to promote and facilitate the restructuring and consolidation of the agricultural sector by encouraging the creation of voluntary agricultural producer organization. To support the policy making process, DG Agriculture and Rural Development has launched a large study $^{3}$ "Support for Farmers' Cooperatives" that provides insights on successful cooperatives and producer organizations as well as on effective support measure (BIJMAN et al., 2012).

The economic role of cooperatives and its position in the food chain needs to be understood in a context where today's agro-food markets are characterized by: thinner margins, greater price and income volatility due to reduced government involvement and international competition; a trend to fewer, larger and more specialized farms, fewer agribusiness firms; innovative products with a shorter life cycle; food consumption increasingly shaped by demands for variety, convenience, food safety and environment friendly; enormous concentration in the final market of consumers; the increasing importance of the role played by information and commercialization technologies (e.g., e-commerce). Despite these changes in market structure and dynamics, with dominance of the demand over the supply, agricultural raw

3. The content of this paper is essentially based on the Portuguese report (REBELO and CALDAS, 2012) prepared by the authors to this study. 
material markets are characterized by vertical coordination, in a way where players (farmers and marketing/processors) engage in a "coopetition", in which all cooperate in the creation of value added, while subsequently competing over its distribution.

Using the theoretical framework suggested in Bijman et al. (2012), that the performance of cooperatives in agro-food chains is related with (a) the position in the food supply chain, (b) the internal governance and (c) the institutional environment, the main objective of this paper is to analyze the economic role of the Portuguese agricultural marketing cooperatives. To achieve this objective, in addition to this introduction (section 1) and the conclusion (section 5), the paper includes an overview of the Portuguese agricultural sector (section 2), the typology of Portuguese cooperatives and position in the agro food chain (section 3), the institutional environment, internal governance and performance of the agricultural cooperatives (section 4).

\section{An Overview of the Portuguese Agricultural Sector}

Table 1 includes indicators that show the evolution of the Portuguese economy and agricultural sector during the last decade. Since 2007, the Portuguese economy witnesses a poor performance, with a tendency to worsen. During the 2007-2011 period, the GDP decreased $0.7 \%$, the unemployment increased, reaching almost $13 \%$ in 2011; the private consumption and investment decreased and the public debt strongly increased, reaching $107.8 \%$ of the GDP in 2012, as a result of repeated annual public deficits. Only the exports, excluding the years of 2008 and 2009, had an opposite behavior, with a good performance in 2010 and 2011.

Between 2007 and 2011, the primary sector (agriculture, forestry and fisheries) presents an erratic performance, with poor performances in 2007 and 2009 and good ones in the remaining years. The year of 2011 witnessed the highest performance, expressed through the positive

Table 1. Indicators on the recent evolution of the Portuguese economy

\begin{tabular}{|c|c|c|c|c|c|c|c|}
\hline & 2000 & 2007 & 2008 & 2009 & $2010 P$ & 2011P & $\begin{array}{c}\text { Average } \\
\text { anual rate } \\
2007-2011\end{array}$ \\
\hline Annual rate of change in the real GDP $(\%)$ & 3.9 & 2.4 & 0.0 & -2.9 & 1.4 & -1.7 & -0.8 \\
\hline Unemployment rate $(\%)$ & 4.0 & 8.0 & 7.6 & 9.5 & 10.8 & 12.8 & 9.8 \\
\hline Annual rate of change in the real Private Consumption $(\%)$ & 3.8 & 2.5 & 1.3 & -2.3 & 2.1 & -3.9 & -0.7 \\
\hline Annual rate of change in the real Public Consumption (\%) & 4.2 & 0.5 & 0.5 & 4.7 & 0.9 & -3.8 & 0.6 \\
\hline Annual rate of change in Investment (\%) & 1.6 & 2.1 & -0.1 & -13.3 & -3.6 & -13.9 & -7.7 \\
\hline Annual rate of change in Exports (\%) & 8.8 & 7.5 & -0.1 & -10.9 & 8.8 & 7.5 & 1.3 \\
\hline Annual rate of change in Imports $(\%)$ & 5.7 & 5.5 & 2.3 & -10.0 & 5.4 & -5.3 & -1.9 \\
\hline Short-cut Interest Rate $(\%)$ & 4.4 & 4.3 & 4.6 & 1.2 & 0.8 & 1.4 & 2.5 \\
\hline Public Debt in $\%$ of the GDP & 48.4 & 68.3 & 71.6 & 83.1 & 93.4 & 107.8 & 84,84 \\
\hline Public Deficit in $\%$ of the GDP & -3.3 & -3.2 & -3.7 & -10.2 & -9.8 & -4.2 & -6.2 \\
\hline $\begin{array}{l}\text { Annual rate of change in the Gross Value Added (GVA) of the } \\
\text { agriculture, forestry and fisheries sectors }(\%)\end{array}$ & -4.7 & -4.6 & 3.1 & -3.8 & 1.0 & 2.8 & -1.5 \\
\hline Agro-forestry sector' share in the GDP (\%) & 7.6 & 5.8 & 5.5 & 5.4 & 5.4 & 5.4 & 5.5 \\
\hline - Agriculture & 2.5 & 1.7 & 1.6 & 1.6 & 1.6 & 1.4 & 1.6 \\
\hline - Agro-food, beverages and tobacco industries & 2.1 & 1.9 & 2.0 & 2.1 & 2.1 & 2.2 & 2.1 \\
\hline - Forestry & 0.8 & 0.5 & 0.4 & 0.4 & 0.4 & 0.4 & 0.4 \\
\hline - Forestry Industry & 2.2 & 1.7 & 1.5 & 1.3 & 1.3 & 1.4 & 1.4 \\
\hline Employment in agriculture (AWU) $-10^{3}$ & 496,8 & 416,1 & 409,8 & 403,5 & 369,9 & 356,6 & 391,2 \\
\hline Employment in agriculture in $\%$ of total employment & 10.0 & 8.4 & 8.2 & 8.3 & 7.7 & 7.7 & 8.1 \\
\hline Employment in the agro-forestry system 1 (in \% of the total) & 14,6 & 12.6 & 12.4 & 12.4 & 11.8 & 11.8 & 12.1 \\
\hline
\end{tabular}

P- Provisional.

Source: GPP (2012) and INE (2012). 
GVA growth of $2.8 \%$, while the Portuguese GDP decreased $1.7 \%$.

The agro-forestry complex represents roughly $5.5 \%$ of the Portuguese GDP and $12.1 \%$ of the country employment while the agricultural sector (agriculture + agro-food industries) represents, respectively, $3.7 \%$ and 8.1\%. Furthermore, during the last decade (GPP, 2012) the sector presents the following results: slight increase in total agricultural production, in volume; preponderance of vegetable production $(52 \%)$ over the animal production $(43 \%)$, a stronger difference in terms of added values $(84 \%$ e $16 \%$, respectively); high concentration of the production in the horticulture, fruits, wine and milk sectors; an agricultural labor productivity growth, at a rate higher than that registered in the economy as a whole, due to an abrupt reduction of small farms, technological improvements (catching-up effect) and a better use of the available resources (technical efficiency).

Based on the results of the Agricultural Census of 2009, INE (2011) summarizes the main trends for the Portuguese farming structure and agricultural system between 1999 and 2009 as follows:

- One of every four farms had ceased its activity but the surface of farms occupies half of the country;

- The small-sized farms continue to prevail, but 2/3 of the Utilized Agricultural Area (UAA) is now managed by farmers with more than 50 ha of UAA;

- UAA increased more than, roughly, 2.5 ha, from an average of 9.3 ha to 12 ha, as a result of the absorption of the surfaces of small farmers by larger ones;

- The number of holdings (as a legal entity of agricultural enterprises) grew $23 \%$, and $27 \%$ of the UAA is managed by them;

- A change in the agricultural landscape, with permanent pasture occupying almost half of the UAA in the most extensive agricultural production systems;

- Enhanced surface reduction of grain cereals in about 244 thousand ha;
- A decrease of $23 \%$ in the irrigated surface;

- Doubling the average size of cattle and pig herds;

- An increase of $10 \%$ in the number of tractors;

- A loss of 443 thousand persons in agricultural family population; however this population still represents $7 \%$ of the resident population;

- Women account for one third of farmers and increased their importance in $8 \%$;

- Farmers age increased on average by 4 years, and it is now of 63 years old;

- The average farmer is a male that completed the 1st cycle of basic education, with only applied training and working exclusively in farming activities about 22 hours per week.

\section{Typology of Portuguese Cooperatives and Position in the Agro Food Chain}

\subsection{Typology}

The Portuguese Cooperative Movement has its roots in the 19th century, although its expansion and deployment was very limited until 1974 (NAMORADO, 1999). During the Constitutional Monarchy, overthrown in 1910, the Portuguese Cooperative Movement was incipient and clearly rooted in the labour movement. During the 1st Republic, from 1910 to 1926, cooperatives were doctrinally oriented, but this orientation did not result in consistent public policies.

During the dictatorship period, between 1926 and 1974, the political power was generically hostile to cooperatives. However, the economic failure of the corporative regime concerning the agricultural sector, led government to encourage agricultural cooperative development in a topdown strategy, strongly supervised by the political power. This positioning is clearly expressed in the Plano de Fomento for wine (TEIXEIRA, 2001; REBELO et al., 2002), milk/dairy, olive oil and fruit cooperatives, in the 1950s and 1960s. 
An important consequence of the democratic revolution of April 25th in 1974 for agricultural cooperatives was the conquest of freedom that led, from this date on, to a strong cooperative expansion both in terms of the number of cooperative members and of the sectors in which they became involved. However, after this expansion, that lasted until the mid-1980s a period of significant cooperative failures occurred, particularly in industries characterised by intense market competition (e.g., the agri-food sector).

In 1980, the Cooperative Code (CC) was passed. The current law is the result of an amendment enacted in 1996 (Law n. 51/96 from September 7). Since 1998, a Cooperative Fiscal Statute (Law no 95/98 from December, 16) exists establishing a specific and a-priori favourable tax regime for cooperatives, comparatively to private firms (exemption of tax on net surplus, excluding the net profits from transactions with third parties, and local tax exemption on real estate). In 2012, this autonomous and specific Cooperative Fiscal Statute became part of the Fiscal Benefits Statute, with a specific article on cooperatives (article 66-A), but the "fundamental matrix" of fiscal support was maintained.

In addition to primary cooperatives and secondary cooperatives, the CC contemplates the existence of federations and confederations of cooperatives. Presently ${ }^{4} 22$ federations and 2 confederations of cooperatives are active. Six federations are present in the agricultural sector: Fenadegas (wine), Fenafrutas (fruit and vegetables), Fenalac (milk), Fenazeites (olive oil) Fenca (production), Fenagro (supply inputs) and, at a higher level two large confederations: Confagri (agricultural and forestry sectors and agricultural credit) and Confecoop (all the other sectors where cooperatives are involved). Since the 1st Congress of the Portuguese Cooperatives, in 1999, these confederations are collaborating under an Inter-cooperative Forum.

4. See www.cases.pt
In their organization and operation, the Portuguese cooperatives observe (comply with) the following cooperative principles, that are an integral part of the declaration on the cooperative identity adopted by the International Cooperative Alliance (ICA): voluntary and open membership; democratic member control; members' economic participation; autonomy and independence; education, training and information; cooperation among cooperatives; and concern for the community.

Primary cooperatives only accept as members ${ }^{5}$, individuals or firms that have transactions with the cooperative (user-owners) and, in its core, they follow the model that in the literature is known as "traditional cooperative", where equity is mainly financed through by member contributions and net surplus (benefits) retained by decision of the general assembly.

Table 2 shows the number of cooperatives, by branch, in Portugal in 2000 and 2010. The total number of cooperatives in 2010 is 3,108, an increase of $4.5 \%$ relatively to 2000 . By branch, agricultural cooperatives are predominant $(31.6 \%$ in 2000 and $28.9 \%$ in 2010) followed by housing and construction and services. Comparing the cooperatives branches that provide public or quasi-public goods (handicraft, culture, education, services and social solidarity) with those that compete with IOFs in the market (agricultural, trade, consumption, credit, fishing and production workers), we observe that, in the last decade, the number of the former increased, while the opposite occurred in the latter case.

5. The article 6 of the CC also considers as cooperatives the regies or cooperatives of public interest, characterized by government participation or other legal persons governed by public law, as well as, jointly or separately, cooperatives and users of products and services produced. 
Table 2. Number of cooperatives (by branch) in Portugal in 2000 and 2010

\begin{tabular}{lccc}
\hline \multicolumn{1}{c}{ Cooperatives } & $\mathbf{2 0 0 0}$ & $\mathbf{2 0 1 0}$ & Change (\%) \\
\hline Branch & & & \\
Agricultural & 931 & 870 & -6.55 \\
Crafts & 48 & 57 & 18.75 \\
Marketing & 60 & 47 & -21.67 \\
Consumption & 205 & 169 & -17.56 \\
Credit & 150 & 100 & -33.33 \\
Culture & 255 & 302 & 18.43 \\
Education & 128 & 139 & 8.59 \\
Housing and construction & 540 & 518 & -4.07 \\
Fishing & 25 & 17 & -32.00 \\
Labour Production & 104 & 71 & -31.73 \\
Services & 419 & 513 & 22.43 \\
Social Solidarity & 85 & 209 & 145.88 \\
Total & 2,950 & 3012 & 2.10 \\
Cooperative Unions & 65 & 72 & 10.77 \\
Federations and confederations of cooperatives & 25 & 24 & -4.00 \\
Total & 2,975 & 3,108 & 4.47 \\
\hline
\end{tabular}

Source: www.cases.pt.

\subsection{Position in agro-food chain}

Detailed information about the quantities of agricultural products marketed through cooperative firms is scarce (COGECA, 2010). However, we can say that, in order of importance, they play a relevant role in the chains of dairy (milk), wine, olive oil and fruit and vegetables. Despite this importance, there are few studies either on the cooperative sector as a whole or on particular aspects of agricultural cooperatives. The market share of cooperatives in the dairy, fruit and vegetables, wine, and olive oil food chains, in 2009, was $70 \%, 25 \%, 42 \%$ and $30 \%$, respectively (Table 3).
In the food chain (REBELO and CALDAS, 2012) the 5 largest agricultural cooperatives belong to the dairy/milk sector. Excluding agricultural supply cooperatives, and in terms of processing/marketing, in descending order, emerge the cooperatives in the wine, fruit and vegetables and olive oil sectors.

In the dairy/milk sector, during the last 20 years, milk cooperatives won a dominant position (ADC, 2010). Almost 2/3 of the raw milk is collected and processed by cooperatives. They also detained $2 / 3$ of the domestic UHT milk market, owning well-known brands, $1 / 3$ of the butter and also a good position in the high added

Table 3. Market share of cooperatives

\begin{tabular}{|c|c|c|c|c|c|}
\hline \multirow[b]{2}{*}{ Sector } & \multicolumn{2}{|c|}{2003} & \multicolumn{2}{|c|}{2009} & \multirow[b]{2}{*}{ Comments } \\
\hline & $\begin{array}{l}\text { Number of } \\
\text { members }\end{array}$ & $\begin{array}{l}\text { Market Share } \\
(\%)\end{array}$ & $\begin{array}{l}\text { Number of } \\
\text { members }\end{array}$ & $\begin{array}{l}\text { Market Share } \\
(\%)\end{array}$ & \\
\hline Fruit and vegetables & n.a, & 35 & n.a. & 25 & $\begin{array}{l}\text { Only fruits. Based on qualitative information } \\
\text { provided by stakeholders of the sector. }\end{array}$ \\
\hline $\begin{array}{l}\text { Olive oil and table } \\
\text { olives }\end{array}$ & n.a & 35 & n.a. & 30 & $\begin{array}{l}\text { Based on qualitative information provided by } \\
\text { stakeholders of the sector. }\end{array}$ \\
\hline Dairy & n.a. & 65 & n.a. & 70 & $\begin{array}{l}\text { Based on qualitative information provided by } \\
\text { stakeholders of the sector. }\end{array}$ \\
\hline Wine & n.a & 54 & n.a. & 42 & $\begin{array}{l}\text { Based on data from the Instituto da Vinha e do } \\
\text { Vinho annual reports. }\end{array}$ \\
\hline
\end{tabular}

Source: Rebelo and Caldas (2012). 
value products (cheese and yoghurts). About 95\% of the products processed by cooperatives are sold in the domestic market or exported to Portuguese speaking countries (i.e., Angola, Mozambique and Cape Verde).

In the wine sector, cooperatives process about $40 \%$ of domestic production, but lost their market share during the last 20 years to IOFs, namely to grape growers who are also processors and bottlers. Although there are some well-known brands of cooperative wines (e.g. Muralhas and Porta da Ravessa), in general, they are present in the low consumer market segment. In terms of international trade, Port wine (REBELO and CALDAS, 2013) has an important contribution to wine exports, representing, in 2008, $26 \%$ of the quantity and $53 \%$ of the value of wine exported, being the price of Port wine more than double of the price of still wines. However, in the last decade emerged a set of Portuguese wines highly rated and awarded in international contests, magazines and newspapers (REBELO and MHUR, 2012), produced by small and medium enterprises, in addition to the classical brands of Porto wine (e.g. Sandeman) and table wine (e.g., Mateus Rosé).

Similarly, in the olive oil sector, cooperatives have been losing their market share. This means that the increased production from the new olive tree plantations, in the southern part of Portugal (Alentejo), was mainly absorbed by investor owned firms (IOFs). The olive cooperatives sold more than $50 \%$ of their production in bulk to packagers/traders while bottled a large part under the brand of the buyer (BOB). The most famous olive oil brands (Gallo, Olveira da Serra and Andorinha), are marketed by IOFs. In recent years, these firms are adopting strategies of upstream vertical integration, adding to marketing the production and processing of olive oil. This product is essentially sold in the domestic market. Brazil, followed by Angola, is the main export market.

In the fruits and vegetables sector the situation is heterogeneous. For fruits (mainly apples and pears) that need a long period of stocking/ conservation in cold facilities, cooperatives hold a $30 \%$ market share of the domestic production; but in the processed fruits and fresh vegetables markets they are almost absent.

With respect to fruit cooperatives it is important to highlight that two generations of cooperatives presently exist: the first generation was founded in the 1950s and 1960s by a large number of culturally/socially heterogeneous farmers, whose mission was mainly to solve the problems of farmers' production, without a clear marketing strategy; the second generation was founded during the last 20 years by homogeneous small groups of farmers with a well-defined marketing strategy.

Although the main market for fruits and vegetables continues to be the domestic market, exports are witnessing an increase in the last years.

\section{Institutional Environment, Internal Governance and Performance of the Agricultural Cooperatives}

\subsection{Institutional environment}

The development of Portuguese agricultural cooperatives is strongly related to the evolution of the political system during the last century, in three distinct periods: the "first republic" period, between 1910 and 1926, characterized by strong social convulsions and political instability, is responsible for the emergence of consumer cooperatives; the "dictatorship regime" period, between 1926 and 1974, is characterized by the promotion of agricultural cooperatives in a topdown process and public control; and since 1974 the "democratic regime" period created the conditions to the free foundation of cooperatives, but without high public support.

In their foundation, organization and governance, agricultural cooperatives are required to follow the legal framework presented in the CC and the specific laws relative to each "branch" that 
complete and develop the CC. In comparison to IOFs, agricultural cooperatives are exempt from corporate tax (IRC) and local taxes related to acquiring property assets. The VAT incident on deliveries made by members is also exempt, being chargeable only when the final price is paid.

Research on agricultural wine cooperatives (TEIXEIRA, 2001; REBELO et al., 2010) allows us to conclude that Portuguese farmers became members of processing/marketing cooperatives, not only to obtain economic benefits (price received by the product delivered to the cooperative), but also according to their social characteristics (size of the farms, level of education, age). The results achieved by those authors indicate that in wine cooperatives ${ }^{6}$ members own small farms (about 1.6 hectare/farm); roughly $80 \%$ of farmers have just primary education; and in age terms, only $12 \%$ are less than 40 years old and $45 \%$ over 60 years old. To overcome the restrictions of the traditional cooperative model, namely the ill definition of property rights, with the inherent problems of free-rider and preference of short time horizon, during the last decade, in the fruit and vegetables sector, production organizations were founded, under the legal regime of private firms or cooperatives, by a small group of homogeneous members.

The agricultural sector as a whole and agricultural cooperatives in particular, are under the umbrella of the competition law that is applied to other sectors. However, according to article 2nd of the EC Regulation No 1184/2006 of April 27th, there are exceptions to the general rules of competition, namely: agreements, decisions and practices integrated in the national market organizations; agreements, decisions and practices that will be needed to satisfy the objectives of the CAP; some agreements between farmers or associations of farmers that belong to a single Member State, since these agreements have

6. The qualitative information collected while preparing Rebelo and Caldas (2012), supports the conclusion that the situation is similar in the other traditional cooperative sectors, namely in olive oil and fruits and less in dairy/ milk. no influence on prices, do not affect competition and do not jeopardise CAP objectives.

Assuming that agricultural markets are becoming increasingly global and competitive, and that farmers are rational economic agents that try to maximize their own wealth, the loss of market share by cooperatives (other than milk) is an indicator that the structural conditions of Portuguese agriculture and the institutional environment, have not been enough attractive to adopt the cooperative model over the other forms of vertical coordination (spot market, contract farming, quasi integration or ownership integration).

Relatively to public intervention in the cooperative sector, Rodrigues (2010, p. 840) maintains that:

"We had two periods of close relation between
the cooperative sector and the political power:
$1980 / 1982$ and $1995 / 1997$. In the last 10 years it
is obvious that the government did not consi-
der this sector relevant".

\subsection{Internal governance}

In their internal governance, cooperatives follow the rules established by the CC from 1996, a Parliament law applicable to all kinds of cooperatives. However, the first specific law for cooperatives was established in 1982.

The article $39^{\circ}$ of the CC defines as mandatory governance bodies of cooperatives: a) the general assembly; b) the board of directors (BoD); c) the supervisory board. The statutes may still provide other bodies, as well as give power to the general assembly or to the BoD to create special committees, of limited duration, in order to perform specific tasks.

Consequently, Portuguese agricultural cooperatives are structured in a two tiersystem (RODRIGUES, 2010). The secondary cooperatives, federations and confederations of cooperatives (article $84^{\circ}$ of the CC) adopt a one-tier system if the number of members of the General Assembly is not sufficient to fulfill the 
positions in the governance bodies. In this case, there will be only a collegiate body, the Assembly of Cooperatives, composed by all members, acting by simple majority, bearing in mind the number of votes that each member is assigned by the Statutes.

The governance bodies of agricultural cooperatives are composed only by members (BoD, supervisory board and president and vicepresident of the general assembly). The members of the bodies are elected among members for a four-year term, unless a shorter period is specified in the bylaws. The $\mathrm{BoD}$ has at least three members, but cooperative bylaws may stipulate a higher (odd) number. By this reason, in some cooperatives the board of directors is composed by five members. The BoD can delegate some of its functions to a manager. The supervisory board is composed of three members (or a higher odd number). The members of these bodies can be remunerated as stipulated by the general assembly, if not forbidden by the bylaws. The majority of the cooperatives do not have professional BoD and/or managers (REBELO et al., 2010).

In the decision-making process, the democratic principle of "one member, one vote" (article 51을 of the CC) is adopted by primary cooperatives. However, there exist two exceptions: cooperatives whose members are exclusively other cooperatives; secondary cooperatives, federations and confederations. In these cases (article $83^{\circ}$ of the CC), the bylaws may attribute to each cooperative member a certain number of votes, both as a function of the number of their members or according to other explicitly stated criteria that, in the context of the democratic principle, receives the approbation of the majority of the members. Some secondary cooperatives adopt a voting rule based in the number of members and in the quantity of product delivered by each associated cooperative.

The Portuguese agricultural cooperatives follow the traditional cooperative principles (i.e., open membership, democratic control, restricted residual claim and benefit to members proportional to patronage), with poorly defined property rights and the inherent difficulty in assuming risky investments that could add value in the medium and long run. Additionally, the smaller ones follow the so-called "Mediterranean model" of governance, characterised by the adoption of the traditional principles and a non-professional management (REBELO et al., 2010). To the question "Is the traditional governance cooperative model, imposed by the $\mathrm{CC}$, a strong restriction to the competition and development of long run entrepreneurial strategies", the answers of cooperative leaders are not unanimous. For cooperatives well positioned in the agri-food chain and with low leverage levels, the compliance of the CC rules is not a relevant restriction, but other solutions/ models are acceptable; the inverse position is expressed by cooperatives with a high leverage, bad positioned in the market and experiencing problems in attracting members/patrons.

\subsection{Performance}

The choice of the appropriate indicator to measure cooperative performance depends on the situation of the stakeholders in the cooperative (e.g., member, manager). Members' perspective (REBELO et al., 2002) on the cooperatives' role can be better explained by answering the following questions: (a) why do farmers want to vertically integrate? (b) why do farmers want/need to integrate jointly rather than individually? In a processing cooperative, the sources of benefits are: scale and scope economies and/or increasing efficiency in assembling and processing raw farm products; elimination of market failures; countervailing market power; farm risk management through pooling or contract arrangement; lower transaction costs in comparison with alternative forms of vertical integration.

A cooperative will only be efficient if its members/patrons are able to get higher net economic benefits (final price of the product delivered, time of receipt, provided runoff, risk 
sharing), than through other alternative forms of vertical integration. Since investor-members are not permitted in Portugal, members' behaviour relative to their own cooperative is mainly related to the final price (patronage refund) of the product delivered. Research on the wine cooperative sector (TEIXEIRA, 2001; REBELO et al., 2002; REBELO et al., 2008) indicates that it is usual for members to exhibit an individualistic and free-riding behavior.

Soboh et al. (2009) present a vast review of the theoretical and empirical economic literature on the performance of agricultural marketing cooperatives. They conclude that empirical studies have failed to address cooperative objectives as represented by the theoretical literature.

Rebelo et al. (2010) applied an econometric model with the goal of checking the performance of the Portuguese Douro Wine cooperatives using two alternative indicators of performance, according to the objective pursed: if the cooperative objective is to maximize the short run financial benefits to members, the patronage refund rate (patronage refund divided by gross revenue) is an appropriate performance indicator; on the other hand, the equity/total asset ratio may be a more appropriate performance indicator for professional managers, to who is preferable a capital structure that favors equity accumulation. Based on the econometric model results, the authors concluded that, according to the theoretical framework, the governance structure has opposite effects on the indicators of performance: when full time directors have bargaining power, cooperatives transfer less revenue to members and try to decrease leverage. These results reinforce the belief that cooperatives structured differently have different and conflicting stakeholder interests. Cooperatives with non-professional management tend to maximize annual revenues from the raw materials delivered; cooperatives with professional directors/managers seek to reinforce equity, with a risk minimizing strategy.

Using as performance indicators the position in the food chain and financial indicators (total assets, equity, and leverage) of the top five agricultural cooperative per sector (REBELO and CALDAS, 2012) it is possible to infer that: milk cooperatives, essentially those located in the Portuguese mainland, present a better and higher performance; in the other sectors the situation is heterogeneous and not so clear, with some cooperatives with high levels of leverage.

Since agricultural cooperatives are located in the core of the food chain, between production and marketing, their efficiency depends on what is occurring upstream (supply) and downstream (demand). The agricultural cooperatives' efficiency is influenced by the social and economic structure of agricultural producers located upstream in the filière that, in the case of Portugal, is characterized as being heterogeneous, atomized, aged, risk averse and with a low educational level. Thus, the most efficient cooperatives are in the sectors in which these weaknesses have been overcome (as is the case of milk and some fruit cooperatives) and also in those that assumed a business approach, with strong leadership, well defined business strategies and an efficient structure, both in human and physical resources and organization.

On the demand side, cooperatives face a commercial distribution that is increasingly strong and concentrated. As stated in AdC (2010): in 2008 the nine largest retail groups, held a share of almost $85 \%$ of the total value of sales in food retail, holding the largest two groups, approximately, $45 \%$ (p. 10); four areas were identified where the bargaining imbalances between distributors and suppliers are clearly relevant (p. 16): (i) unilateral imposition of conditions (i. e., negotiation of a typical contract); (ii) discounts and other inducements; (iii) penalties; and (iv) payment times. Although these practices do not contravene the EU and Portuguese legislation on competition, in the absence of a clear abuse of market power, have negative repercussions on sales prices, which, at the end, affect the prices paid to agricultural producers. 


\section{Conclusion}

Agricultural cooperatives are an upstream and/or downstream extension of agricultural activities and their evolution reflects, and it is a consequence, of the structural transformations occurred in Portuguese agriculture.

The Portuguese agricultural cooperative movement gained relevance in 1960s, as an answer to market failures. As the agricultural markets are becoming increasingly global and competitive, the loss of market share by cooperatives (other than milk) is an indicator that the structural conditions of Portuguese agriculture and the institutional environment, have not been enough attractive to adopt the cooperative model over the other forms of vertical coordination (spot market, contract farming, quasi integration, or ownership integration).

There are different factors that explain the economic performance of Portuguese agricultural cooperatives, namely the socio-economic characteristics of members and leadership. The obligation of cooperatives to follow the legal framework contemplated in the CC and the lack of flexibility of the governance model, are cited as barriers to the competitiveness of cooperatives, particularly to the oldest ones, with a large and heterogeneous membership (in economic, social and cultural terms).

Consequently the legal framework needs to be revised to allow cooperatives to evolve into a new generation of cooperatives ${ }^{7}$ (proportional investment cooperatives, member investor cooperatives, cooperatives with capital-seeking entities), as pointed out by cooperative' stakeholders. Although the adoption of a new cooperative model, as alternative to

7. Somehow, the milk sector solved this problem by adopting a pyramid model, with the first degree cooperatives aggregating the producers, secondary cooperatives in the intermediate stage and a private commercial company (Lactogal, SA), at the top of the pyramid, owned in equal shares by three cooperatives (Lacticoop, Agros and Proleite). At the same time they were able to constitute a strong business group. This process was supported by a strategic vision and a strong and sustained leadership. the traditional one, is important, it is not the panacea for the structural illnesses of Portuguese agriculture (atomized, reduced innovation, low productivity, aged farmers, low educational level and risk averse). The legal emergence of these new models would provide a wider range of options in solving some of the current problems in the sector.

Overall, if the policy objectives are to maintain a high number of small producers in the agri-food chain, especially in peripheral regions, it is important to secure the existence of economically strong agricultural cooperatives, able to face a global demand and the increasing market power of larger retailers. Hence, a specific financial envelope must be defined for cooperatives, including integrated support for material and immaterial investments for their technical conversion and size increase (scale economies), changes in the structure of property rights, professionalization of management, staff training, technical support to associates and marketing strategies.

\section{References}

AdC - Autoridade da Concorrência (2010). Relatório Final sobre Relações Comerciais entre a Distribuição Alimentar e os seus Fornecedores. Lisboa, <http://www. concorrencia.pt $>$.

BIJMAN, J. et al. Support for Farmers'Cooperatives. Final Report. Wageningen: Wageningen UR, 2012. < http:// ec.europa.eu/agriculture/external-studies/2012/ support-farmers-coop/fulltext_en.pdf > and < http:// www.wageningenur.nl/en/show/Support-for-FarmersCooperatives.htm $>$.

COGECA - European agri-cooperatives. Agricultural Co-operatives in Europe: Main Issues and Trends. Brussels, 2010. Disponível em: <http://www.copa-cogeca.be/ img/user/file/COGECA_BOOK_2011>.

GPP - Gabinete de Planeamento e Políticas. A Agricultura na Economia Portuguesa: Envolvente, Importância e Evolução Recente, 2011, 2012. Ministério da Agricultura do Mar, do Ambiente e do Ordenamento do Território, Dezembro de 2012, Lisboa. www.gpp.pt/ pbl/Period/Agricultura_Economia_Portuguesa_2011. pdf. 
INE - Instituto Nacional de Estatística. Recenseamento Agrícola 2009: Análise dos principais resultados. INE, Lisboa, Edição 2011. http://ra09.ine.pt

INE - Instituto Nacional de Estatística (2012). Contas Nacionais. INE, Lisboa, www.ine.pt

NAMORADO, R. Cooperativismo e Politica em Portugal. Cooperativismo, Emprego e Economia Social, Editors Carlos P. Barros e J.C. Gomes Santos, Vulgata, Lisboa, 1999.

REBELO, J., CALDAS, J. and TEIXEIRA, M. Economic Role, Property Rights, Labour Skills and Technology in the Portuguese Wine Co-operatives. Annals of Public and Co-operative Economics, v. 73, p. 111-133, 2002.

, CALDAS, J. and MATULICH, S. C. Manager Power, Member Behaviour and Capital Structure: Portuguese Douro Wine Cooperatives. Agricultural Economics Review, v. 9, n. 2, p. 5-13, 2008.

,CALDAS, J. and MATULICH, S. C. Performance of Traditional Cooperatives: The Portuguese Douro Wine Cooperatives. Economya Agraria y Recursos Naturales, v. 10, n. 2, p. 143-158, 2010. . and CALDAS, J. Support for Farmers' Cooperatives; Country Report Portugal. Wageningen, Wageningen,
UR, 2012. http://www.wageningenur.nl/en/show/ Support-for-Farmers-Cooperatives.htm . and CALDAS, J. The Douro wine region: a cluster approach. Journal of Wine Research, v. 24, n. 1, p. 19-37, 2013.

. and MUHR, D. Innovation in Wine SMEs: The Douro Boys Informal Network. Studies in Agricultural Economics, v. 114, n. 10, p. 1-15, 2012.

RODRIGUES, J. A. Study on the implementation of the Regulation 1435/2003 on the Statute for European Co-operative Society (SCE) - National Report: Portugal, 2010. Available at: <http://ec.europa.eu/enterprise/ policies/sme/files/sce_final_study_part_ii_national_ reports.pdf $>$.

SOBOH, R., LANSINK, A., GIESEN, G. and van DIJK, G. Performance Measurement of the Agricultural Marketing Cooperatives: The Gap between Theory and Practice. Review of Agricultural Economics, v. 31, n. 3, p. 446-469, 2009.

TEIXEIRA, M. Função, Direitos de Propriedade $e$ Estratégias nas Cooperativas Vitivinícolas Portuguesas. Tese de doutoramento, UTAD, Vila Real, Portugal, 2001. 